\begin{tabular}{|c|c|c|c|c|c|}
\hline $\begin{array}{l}\text { Year. } \\
\text { II } 38\end{array}$ & & Moon. & & Remarks. & \\
\hline 1139 & $\ldots$ & 2,10 & & & \\
\hline I 145 & $\ldots$ & 6 & $\ldots$ & Black shadows and spots. & \\
\hline 1160 & $\ldots$ & 8 & & & \\
\hline 1185 & $\ldots$ & I & $\cdots$ & Size of an egg. & \\
\hline I 186 & $\cdots$ & 5 & $\cdots$ & ", & \\
\hline 193 & $\cdots$ & $\int_{12}^{\text {II }}$ & & & \\
\hline $\begin{array}{l}1200 \\
1202\end{array}$ & $\cdots$ & $8, \mathbf{I} 2$ & & & \\
\hline $\begin{array}{l}1202 \\
1204\end{array}$ & $\cdots$ & 12 & $\cdots$ & Size of an egg. & \\
\hline 1205 & $\ldots$ & 4 & & & \\
\hline 1238 & $\ldots$ & IO & & & \\
\hline 1276 & $\ldots$ & - & $\cdots$ & Size of a goose's egg. & \\
\hline $\mathbf{I} 370$ & $\cdots$ & - & $\cdots$ & $\begin{array}{l}\text { Spots were frequently } \\
\text { during this year. }\end{array}$ & observed \\
\hline 2511 & $\ldots$ & 5 & $\ldots$ & Black shadows. & \\
\hline 1529 & $\cdots$ & 2 & $\cdots$ & , & \\
\hline 1617 & ... & - & & ALEXANDER & Hosie \\
\hline
\end{tabular}

NATIONAL WATER-SUPPLY EXHIBITION

H YDE PARK and Trafalgar Square experiences have very plainly shown that the simplest way to induce a clamorous populace to forget what they fancy they want, is to let them hold their meetings and pass resolutions. It is a matter of such very small exertion to hold up a hand in favour of a resolution compared with taking any personal trouble to see that any steps are taken towards carrying it into effect. Human nature is only in certain phases influenced by a man's occupation, and whether resolutions are passed by "labourers" or by "professional gentlemen," they stand much the same chance of being forgotten after the press has recorded that they have been passed. Last year the Society of Arts in loyal response to the request of its Royal President, held a conference to discuss the watersupply question. After two days' work a resolution was carried urging that a small scientific commission should be appointed to collect information and suggest further inquiries on the subject. Twelve months elapsed and a few days ago another conference was held, when it was made known that the only step taken with regard to that resolution was that just before the Conference it had reached the Lords of the Treasury. Last year the Society directed that a résumé and sort of index should be made of what had been done by Parliamentary inquiries and official reports with regard to water-supplies, and the result was a volume called "Notes on Previous Inquiries," which, though very incomplete, may serve as a basis for a larger and more comprehensive work. The very fact of the imperfections in these notes showed to those more immediately connected with their compilation the need of enlisting wider sympathies if anything of real value was to be printed. A letter in the Times of April I4 of this year mentioned that although the notes had been published for many months, "not a single word" had been sent in response to the request printed on the back of the titlepage that suggestions or corrections should be sent to the secretary. The idea was then suggested of founding a permanent free museum for the purpose of keeping before the public mind those subjects, apart from the question of low rates only, which should be considered in arranging water-supplies. It was decided that a temporary exhibition should be first tried as an experiment and after some difficulties in finding it a locale, the management of the Royal Aquarium kindly arranged for the use of the south gallery for the purpose. This exhibition is now open and a handbook is issued. It is marked "under revision," and on the title-page attention is appropriately drawn to the fact that it is the first public exhibition of the kind.

This handbook, we are told, has been drawn up under great disadvantages in many ways. One great difficulty has been that the exhibition has grown beyond what seemed at first likely to be its extent, and entries for the handbook have come from time to time, though but slowly. This was, perhaps, to be expected in an exhibition, the first of its kind, which was, therefore, to some extent, an experiment; and that many should hold aloof till success was assured was but natural. Although this gradual growth is a matter that must be a satisfaction to those interested in spreading a knowledge of what a study of water-supply means, it has entailed much unexpected labour on the part of the management.

Among those who have helped in the scientific sections are-Col. Beaumont, M.P., Col. Bolton, Baldwin Latham, F.R.S., J. G. Symons, F.R.S., J. E. Gardner, F.S.A., Dr. Granville Cole, Prof. Wanklyn, Prof. G. Bischoff, W. Cooper, Joseph Lucas, F.G.S., A. T. Atchison, M.A., C. E. De Rance, H.M.G.S., F.G.S., J. B. Jordan, F.G.S.

The comprehensive scope of the exhibition may be gathered from the following list of the sections into which it is divided :-

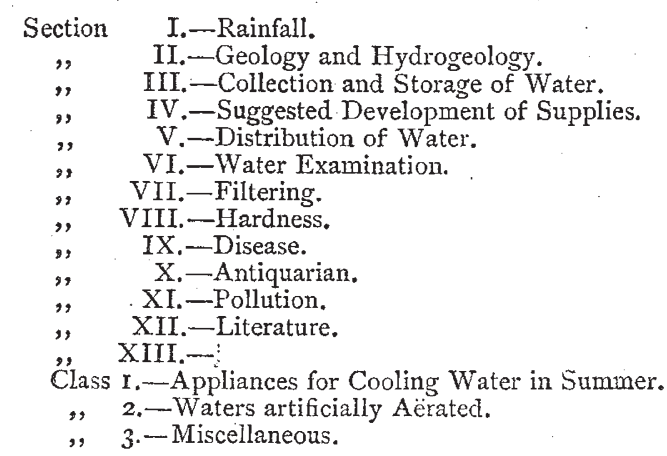

A scientific committee has been formed to draw up a report on the exhibition, especially to point out what defects should be remedied in future exhibitions of the kind, and it is announced that next week "demonstrations" will be given on the sections embracing scientific apparatus.

\section{NATURAL SCIENCE DEGREES AT OXFORD}

MANY of our readers have no doubt noticed the scheme which some soi-disant "friends of science" in authority at Oxford have brought forward professedly in the interests of science. One of the prime movers in the new scheme for the creation of B.N.S. and M.N.S. degrees is Canon Liddon, who insists that for the degree of Arts Greek shall be indispensable, but for the inferior degrees in science may be dispensed with. Since the meeting of congregation at which the scheme was discussed, there has been much correspondence in the Times on the subject, the letters of most importance being those of Canon Liddon and Prof. Odling. The former in his correspondence professes to have the interests of natural science purely at heart in the creation of the new degree, which, he maintains, would give facilities to a much wider class to obtain the stamp of the University than if Greek were insisted on, as he maintains must be the case with the degree of the university. The opposition of Prof. Odling and those who think with him, is not to the creation of a degree in natural science, but to any course that would degrade it in public estimation. He urges on the university the desirability of framing such statutes in reference to any such degree, as shall assure it a high place in general estimation, and shall more especially obtain for it the approval and sympathy of the cultivators of natural science. He considers it important to this end that the possession of a degree in natural science shall imply on the part of the student, first, general cultivation, and second, special knowledge in some branch of science. But according to the proposed innovation, if 